УДК 338:631.92

https://doi.org/10.33296/2707-0654-8(16)-12

\title{
ВИГОВСЬКА Валентина
}

доктор економічних наук, професор, Національний університет «Чернігівська політехніка», м. Чернігів, Україна

ORCIDiD: https://orcid.org/0000-0001-8632-9656

\section{ПИЩЕНКО Олександр}

кандидат економічних наук, Національний університет «Чернігівська політехніка», м. Чернігів, Україна

ORCIDiD: http://orcid.org/0000-0353-8238-8544

\section{НАПРЯМИ ТА ІНДИКАТОРИ ІНСТИТУЦЙНОГО ЗАБЕЗПЕЧЕННЯ ЕКОЛОГО-ЕКОНОМІЧНОЇ БЕЗПЕКИ АГРАРНОГО СЕКТОРУ УКРАЇНИ}

\begin{abstract}
Анотація. Доведено актуальність дослідження інституційного забезпечення еколого-економічної безпеки аграрного сектору. Результати проведеного аналізу дозволили констатувати, що в Україні на сьогоднішній день не існує скоординованого механізму регулювання еколого-економічної безпеки аграрного сектору, органи регулювання діють за централізованою моделлю, організаційна структура та функціональна система не відповідає вимогам забезпечення еколого-економічної безпеки аграрного сектору. Обгрунтовано стратегічні напрями нейтралізації конфліктних ситуацій та гармонізації інтересів суб'єктів забезпечення еколого-економічної безпеки аграрного сектору, які передбачають: зміну парадигми розвитку аграрного сектору 3 технократичної на екологічно безпечну; формування дієвого механізму регулювання еколого-економічної безпеки аграрного сектору завдяки раціональному поєднанню ринкових та державних важелів впливу, спрямованих на передбачення та попередження загроз; оптимізацію інституційного забезпечення еколого-економічної безпеки аграрного сектору. Інституціоналізація процесу забезпечення еколого-економічної безпеки включає в себе залучення широкого кола учасників разом з їх власними цілями та притаманними їм функціями. Функціонування аграрного сектору залежить від наступних характеристик господарської динаміки: матеріальні потреби, господарські орієнтири та інтереси, визначена під їх впливом мотивація до господарської діяльності. Перш за все, суб'єктами забезпечення екологоекономічної безпеки є органи законодавчої, виконавчої та судової влади в


межах своїх встановлених законом повноважень.

Ключові слова: аграрний сектор, еколого-економічна безпека, інституційний, забезпечення.

Вступ. Аналіз сучасного стану механізму регулювання екологоекономічної безпеки аграрного сектору на практиці можна вважати стратегічним напрямом, дія якого спрямована на визначення рівня екологоекономічної безпеки аграрного сектору та відповідності його стану світовим тенденціям в регулюванні аграрним сектором. Даний підхід до дослідження регулювання еколого-економічної безпеки аграрного сектору передбачає виконання комплексу заходів, до яких належать: по-перше, системноструктурний аналіз, проведений для виявлення складових механізму регулювання та відносин координації та субординації між ними (з'ясування моделі регулювання); по-друге, функціональний аналіз сучасного стану нормативно-правового забезпечення еколого-економічної безпеки аграрного сектору у напрямку визначення повноти виконуваних функцій та узгодженості дій; по-третє, аналіз організаційної будови органів регулювання аграрним виробництвом, що дає відповіді на питання ï відповідності виконуваним функціям та моделі регулювання еколого-економічної безпеки, тобто його інституційне забезпечення; по-четверте, аналіз впливу зовнішнього i внутрішнього середовища на функціонування відповідних управлінських структур, що мають відношення до регулювання еколого-економічної безпеки аграрного сектору в сучасних ринкових умовах. Тому для системного уявлення еколого-економічної безпеки аграрного сектору варто акцентувати увагу на інституціоналізмі, що є одним із способів дослідження чинників виникнення еколого-економічної кризи в Україні. Інституціональний підхід характеризується своєю функціональністю в контексті розробки заходів еколого-економічної політики і $є$ дієвим інструментом для інтерпретації та 
прогнозування екологічно-збалансованого розвитку всієї країни та аграрного сектору зокрема.

Аналіз останніх досліджень і публікацій. В дослідженнях вітчизняних вчених, присвячених проблемам інституційного регулювання екологоекономічної безпеки аграрного виробництва, в більшій мірі досліджується стан речей, що склався в даній сфері, і в меншій мірі надаються пропозиції з іiі удосконалення.

Управлінські аспекти інституційного забезпечення еколого-економічної безпеки аграрного сектору розроблялися у працях: В. Борщевського, О. Манойленка, А. Никифорова, В. Русана, П. Саблук, М.Скорик, А. Черепа та ін..

Незважаючи на широкий спектр напрямів дослідження особливостей державного регулювання еколого-економічної безпеки аграрного сектору, у працях зазначених учених практично не знайшли відображення питання розробки ефективного інструментарію інституційного регулювання екологоекономічної безпеки аграрного сектору.

Цілі даної наукової роботи - виявити сучасні тренди щодо обгрунтування науково-прикладних засад інституційного забезпечення екологоекономічної безпеки аграрного сектору.

Виклад основного матеріалу дослідження. Чинники впливу на інституціональну складову механізму регулювання еколого-економічної безпеки аграрного сектору відрізняються в залежності від їх походження, напрямів та значимості впливу. На сьогодні в Україні існує сукупність проблем функціонування інституціонального середовища: висока нестабільність формальних правил, наявність високого рівня корупції, що викривляє неформальні правила, недосконалість судової системи, неефективна робота політичних організацій, що створюють перепони на шляху розвитку добросовісної конкуренції, низький рівень розвитку соціально-економічних організацій, наприклад, об'єднань продавців чи покупців, які могли б захищати

\footnotetext{
(C) Українська інженерно-педагогічна академія

(C) ГО «Школа адаптивного управління сочіально-педагогічними системами»

(C) Виговська В., Пищенко О.
} 
права всіх учасників ринку від негативного впливу діяльності порушників неформальних та формальних інститутів [1].

Інституціональне забезпечення регулювання еколого-економічної безпеки аграрного сектору повинне відповідати інтересам суспільства i сприяти досягненню його цілей. Наявність протиріч $є$ природним явищем унаслідок різноманітності інтересів і цілей кожного громадянина, організацій і соціальних груп, однак структурне їх впорядкування $є$ обов'язковим. Саме інститути та інституціональні норми створюють передумови i умови для раціональної поведінки суб’єктів механізму [2]. Загалом, інститути умовно розділяють на формальні та неформальні (табл. 1).

Таблиця 1

Формальні та неформальні інститути забезпечення еколого-економічної

безпеки аграрного сектору

\begin{tabular}{|c|c|c|}
\hline \multirow{2}{*}{$\begin{array}{c}\text { Складові еколого- } \\
\text { економічної безпеки }\end{array}$} & \multicolumn{2}{|c|}{ Інститути } \\
\hline & Формальні & Неформальні \\
\hline $\begin{array}{l}\text { Інформаційно- } \\
\text { аналітична }\end{array}$ & $\begin{array}{c}\text { еколого-економічний аудит } \\
\text { та моніторинг }\end{array}$ & $\begin{array}{c}\text { громадський еколого- } \\
\text { економічний контроль; засоби } \\
\text { масової інформації }\end{array}$ \\
\hline Забезпечувальна & $\begin{array}{c}\text { еколого-економічна політика; } \\
\text { нормативно-правові акти; } \\
\text { ліцензування; }\end{array}$ & $\begin{array}{c}\text { освіта і виховання; еколого- } \\
\text { економічна свідомість; етика та } \\
\text { мораль; культурні цінності }\end{array}$ \\
\hline $\begin{array}{l}\text { Функціонально- } \\
\text { інструментальна }\end{array}$ & $\begin{array}{c}\text { стандартизації та } \\
\text { сертифікації; субсидування } \\
\text { та штрафні санкції; } \\
\text { кредитування; страхування та } \\
\text { компенсації; фіскальне } \\
\text { регулювання; еколого- } \\
\text { економічний менеджмент }\end{array}$ & професійна самосвідомість \\
\hline Результативно-цільова & $\begin{array}{c}\text { правова відповідальність; } \\
\text { державний еколого- } \\
\text { економічний контроль }\end{array}$ & $\begin{array}{l}\text { громадський еколого- } \\
\text { економічний контроль }\end{array}$ \\
\hline
\end{tabular}

Джерело: сформовано автором.

Формальні інститути відображені в законодавчих та інших нормативноправових актах та передбачають обов’язковість їх дотримання через систему 
державного контролю. Ці інститути здійснюють потужний вплив на економічну ситуацію за допомогою функціонування визначених установ та організацій. На противагу їм, неформальні інститути характеризуються відсутністю чітко визначених меж та здійснюють вплив на економічну систему у формі усних домовленостей та договорів, які спрямовані на досягнення спільної мети та формують соціально-культурні норми та правила поведінки [3].

Для врегулювання конфліктності суспільних відносин втручання держави $\epsilon$ обов'язковим (зокрема через право голосу, вибору тощо) і має в своєму розпорядженні відповідні інституційні важелі впливу. Звідси слідує, що забезпечення процесу дотримання принципів еколого-економічної безпеки потрібно покласти на діяльність формальних інститутів як таких, чий обсяг функцій та можливостей регулюється законами або іншими нормативноправовими актами. Дія таких інститутів та механізми захисту їх нормального функціонування підтримується, в основному, державними органами та забезпечується на державному рівні [4].

Інституціоналізація процесу забезпечення еколого-економічної безпеки включає в себе залучення широкого кола учасників разом з їх власними цілями та притаманними їм функціями. Функціонування аграрного сектору залежить від наступних характеристик господарської динаміки: матеріальні потреби, господарські орієнтири та інтереси, визначена під їх впливом мотивація до господарської діяльності. Перш за все, суб'єктами забезпечення екологоекономічної безпеки є органи законодавчої, виконавчої та судової влади в межах своїх встановлених законом повноважень. На другому рівні, так званому рівні «вторинної інституціоналізації», в ролі суб'єкта забезпечення екологоекономічної безпеки виступають міністерства, відомства, служби та агентства, на плечі яких і покладена фактична реалізація еколого-економічної безпеки в країні. I на останньому, третьому рівні знаходяться структурні підрозділи зазначених вище відомств, які безпосередньо відповідають за різні напрями 
забезпечення еколого-економічної безпеки [5].

Зміст регулювання еколого-економічної безпеки аграрного сектору визначає поєднання в єдине ціле двох векторів регулювання - галуззю аграрного сектору та регулювання в сфері еколого-економічної безпеки, а його роль у становленні безпеки на рівні держави - визначає існування структури регулювання на чотирьох рівнях, яка включає в себе державний, місцевого самоврядування, громадський i господарський рівні регулювання. Тобто, актуальності набувають питання дослідження суб’єктів регулювання аграрним виробництвом та його еколого-економічною безпекою у контексті інституційного забезпечення механізму регулювання еколого-економічної безпеки аграрного сектору.

Так як дослідження проблематики регулювання еколого-економічної безпеки аграрного виробництва проводиться на мезо- та макро-рівнях, то органи регулювання як такі, що формують мікро-рівень регулювання у проведений нами аналіз не будуть включені.

Структура суб’єктів регулювання еколого-економічної безпеки аграрного сектору включає:

1) суб’єкти державної влади: Президент України; Верховна Рада України; Кабінет Міністрів України; Міністерство аграрної політики та продовольства України та урядові органи, що діють в його складі - Державна служба 3 охорони прав на сорти рослин, Український інститут експертизи сортів рослин, Державна інспекція 3 контролю якості сільськогосподарської продукції та моніторингу іï ринку, Державний департамент ветеринарної медицини; Міністерство охорони навколишнього природного середовища та діючі в його складі Державна еколого-економічна інспекція; Державний комітет України по водному господарству; Державний комітет із земельних ресурсів та Державна інспекція з контролю за використанням та охороною земель.

До державних структур, які мають опосередковане відношення до

\footnotetext{
(C) Українська інженерно-педагогічна академія

(C) ГО «Школа адаптивного управління сочіально-педагогічними системами»

(C) Виговська В., Пищенко О.
} 
забезпечення еколого-економічної безпеки аграрного сектору, а саме Міністерство України з питань надзвичайних ситуацій та у справах захисту населення від наслідків Чорнобильської катастрофи, Державна служба заповідної справи та Державна гідрометеорологічна служба Міністерства охорони навколишнього природного середовища, Державний комітет стандартизації, метрології та сертифікації України, Державний департамент по нагляду за охороною праці, Міністерство охорони здоров'я не доцільно, на нашу думку, включати у результати проведеного аналізу;

2) регіональні (обласні та районні) відділення центральних органів влади, представлені в попередньому пункті державних органів (крім перших трьох), які виділені в окрему групу, оскільки мають подвійне підпорядкування профільному відомству та місцевим органам самоврядування (обласним та районним радам). Дані суб'єкти регулювання складаються 3 управлінь агропромислового розвитку, екології та природних ресурсів, земельних ресурсів, водних ресурсів та територіальних представництв урядових органів регулювання та контрольно-інспекційних служб Міністерства аграрної політики та продовольства України і Міністерства охорони навколишнього природного середовища;

3) суб'єкти механізму регулювання еколого-економічної безпеки аграрного сектору на рівні децентралізованого регулювання:

3.1) органи місцевого самоврядування - обласні, районні, сільські та селищні ради та відповідні виконавчі комітети, які відповідно до ст. 4 Закону України «Про національну безпеку» віднесено до суб'єктів забезпечення національної безпеки;

3.2) громадські професійні організації, до яких входять: Аграрний Союз України, Міжнародна асоціація виробників органічної продукції «Біолан Україна», Федерація органічного руху України, Спілка учасників органічного агровиробництва «Натурпродукт», Асоціація фермерів та приватних

\footnotetext{
(C) Українська інженерно-педагогічна академія

(C) ГО «Школа адаптивного управління сочіально-педагогічними системами»

(C) Виговська В., Пищенко О.
} 
землевласників України, товариства споживачів, Науково-дослідний центр незалежних споживчих експертиз «ТЕСТ», Центр еколого-економічної безпеки споживачів «Екостандарт» тощо;

4) інформаційно-консультаційні служби, які, незважаючи на їх різні форми власності, виділені нами в окрему групу через специфічність виконуваних функцій i важливу роль, яку вони можуть відіграти і вже відіграють у забезпеченні еколого-економічної безпеки аграрного сектору.

3 огляду на те, що у відтворювальному процесі збалансоване природокористування передбачає як економічний процес експлуатації природних ресурсів, так і їх охорону, варто сформувати напрями інтеграції різних інтересів суб'єктів забезпечення еколого-економічної безпеки аграрного сектору, що спираються на виявлення конфліктів цілей суб'єктів організаційноекономічного забезпечення еколого-економічної безпеки в аграрному секторі та ïх ліквідацію 3 використанням принципів системного підходу та інструментарію конфлікт-менеджменту [6]. Як приклад, основний конфлікт в питанні забезпечення еколого-економічної безпеки аграрного сектору, проявляється коли стикаються економічні інтереси (місцеві органи влади зацікавлені в максимальному використанні природних ресурсів господарюючими суб'єктами, оскільки в такому разі отримають максимальні надходження до бюджету) та екологічні (місцеві органи влади зацікавлені в збереженні природно-ресурсного потенціалу регіону, що можливо лише при мінімальному втручанні в природні екосистеми) [7-8].

Для забезпечення ефективної реалізації регулювання еколого-економічної безпеки аграрного сектору потрібно вирішувати всі наявні та можливі конфлікти, враховувати інтереси всіх зацікавлених сторін, навіть тих, які відносяться до різних інститутів. Взаємодія суб’єктів господарювання (їх мета максимальний прибуток за мінімальних витрат), державних органів влади (функціонування механізму регулювання еколого-економічної безпеки

\footnotetext{
(C) Українська інженерно-педагогічна академія

(C) ГО «Школа адаптивного управління сочіально-педагогічними системами»

(C) Виговська В., Пищенко О.
} 
аграрного сектору) та суспільства (бажання до покращення умов життя, безпечні екологічні умови, зменшення антропогенного навантаження) призводить до формування різноспрямованих інтересів щодо єдиної мети створення ефективного механізму забезпечення еколого-економічної безпеки аграрного сектору.

Досліджуючи питання взаємодії стратегічних і тактичних цілей механізму регулювання еколого-економічної безпеки аграрного сектору у контексті сучасних ринкових перетворень та функцій державних органів влади і органів місцевого самоврядування, можна оцінити не тільки їх конфліктність, але й визначити ефективність розподілення завдань між ними, встановити можливе дублювання. Для вирішення конфлікту цілей, необхідно детально розглянути кожну ціль та диференціювати їі до тих пір, поки суть конфлікту не проявить себе. Лише в такому випадку можна досягти компромісного рішення, сформувавши необхідні для цього інструменти та забезпечивши процес ліквідації протиріч у процесі забезпечення еколого-економічної безпеки аграрного сектору.

Результати проведеного аналізу проблем функціонування механізму регулювання еколого-економічної безпеки аграрного сектору дозволили обгрунтувати стратегічні напрями нейтралізації конфліктних ситуацій та гармонізації інтересів суб'єктів забезпечення еколого-економічної безпеки аграрного сектору (рис. 1), які передбачають:

- зміну парадигми розвитку аграрного сектору 3 технократичної на екологічно безпечну;

- формування дієвого механізму регулювання еколого-економічної безпеки аграрного сектору завдяки раціональному поєднанню ринкових та державних важелів впливу, спрямованих на передбачення та попередження загроз;

- оптимізацію інституційного забезпечення еколого-економічної безпеки 
Електронне наукове фахове видання «Адаптивне управління: теорія і практика»

аграрного сектору в Україні.

Також варто відзначити, що збалансованість інтересів суб’єктів механізму регулювання еколого-економічною безпекою аграрного сектору досягається шляхом об'єднання зусиль у напрямку регулювання екологоекономічною безпекою та реалізації стратегічних пріоритетів державної еколого-економічної політики через формування еколого-економічної свідомості населення, належне інноваційне забезпечення аграрного сектору, розробку відповідної законодавчої та нормативно-правової бази тощо. 


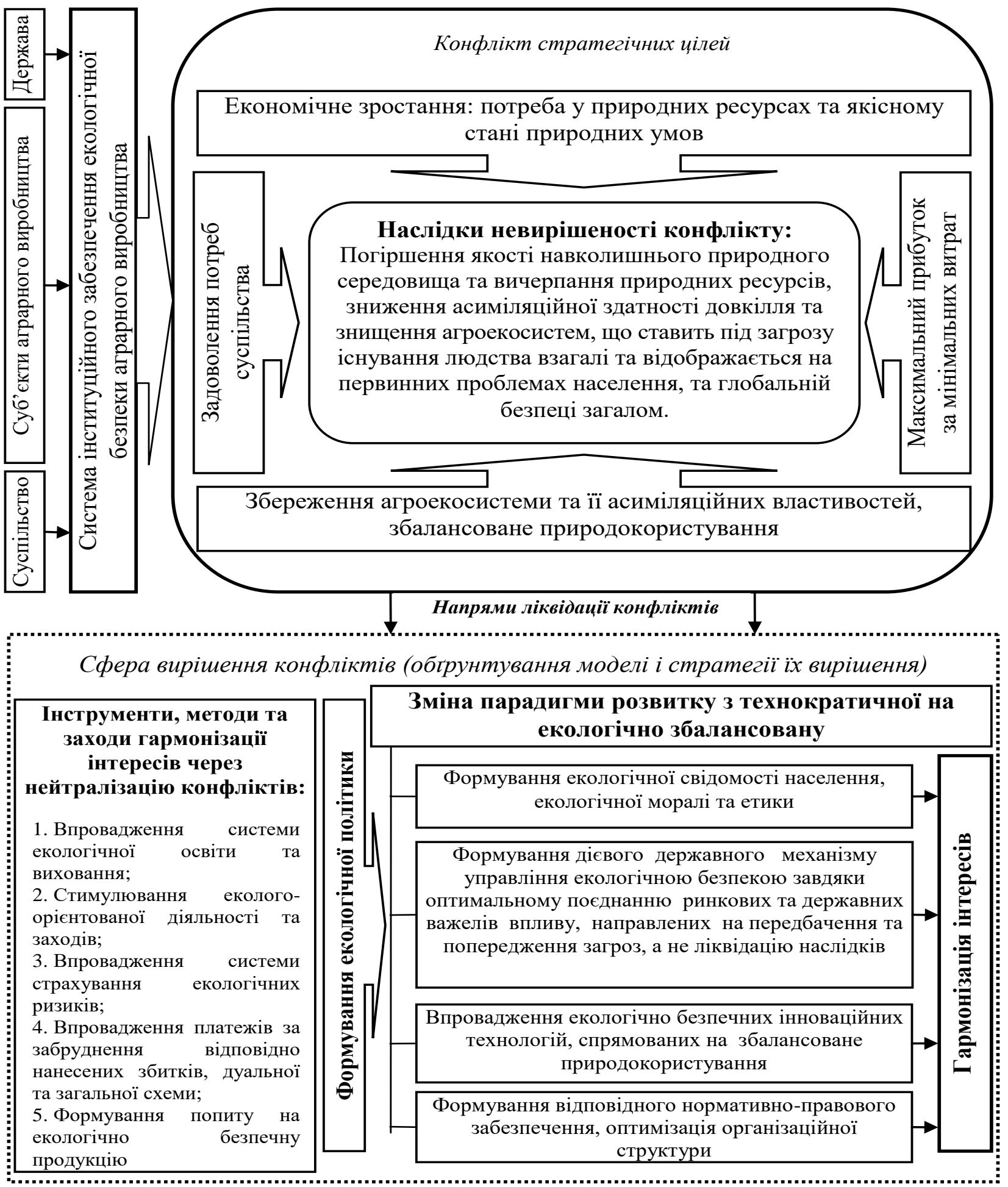

\title{
Рис. 1. Структурно-функціональна схема нейтралізації конфліктних ситуацій та гармонізації інтересів суб'сктів механізму регулювання еколого-економічної безпеки аграрного сектору
}

\author{
Джерело: авторська розробка.
}

\footnotetext{
(C) Украӥнська інженерно-педагогічна академія

(C) ГО «Школа адаптивного управління сочіально-педагогічними системами»

(C) Виговська В., Пищенко О.
} 


\section{Висновки i напрями подальших наукових досліджень.}

Інституціоналізація процесу забезпечення еколого-економічної безпеки включає в себе залучення широкого кола учасників разом з їх власними цілями та притаманними їм функціями. Функціонування аграрного сектору залежить від наступних характеристик господарської динаміки: матеріальні потреби, господарські орієнтири та інтереси, визначена під їх впливом мотивація до господарської діяльності. Перш за все, суб’єктами забезпечення екологоекономічної безпеки є органи законодавчої, виконавчої та судової влади в межах своїх встановлених законом повноважень. На другому рівні, так званому рівні «вторинної інституціоналізації», в ролі суб’єкта забезпечення екологоекономічної безпеки виступають міністерства, відомства, служби та агентства, на плечі яких і покладена фактична реалізація еколого-економічної безпеки в країні. I на останньому, третьому рівні знаходяться структурні підрозділи зазначених вище відомств, які безпосередньо відповідають за різні напрями забезпечення еколого-економічної безпеки. Обгрунтовані стратегічні напрями нейтралізації конфліктних ситуацій та гармонізації інтересів суб’єктів забезпечення еколого-економічної безпеки аграрного сектору, які передбачають: зміну парадигми розвитку аграрного сектору 3 технократичної на екологічно безпечну; формування дієвого механізму регулювання екологоекономічної безпеки аграрного сектору завдяки раціональному поєднанню ринкових та державних важелів впливу, спрямованих на передбачення та попередження загроз; оптимізацію інституційного забезпечення екологоекономічної безпеки аграрного сектору в Україні.

\section{Використана література:}

1. Буркинський Б. В., Галушкіна Т. П., Реутов В. С. «Зелена» економіка крізь призму трансформаційних зрушень в Україні: монографія. Одеса: Підприємство «Фєнікс», 2011. 348 с.

2. Гайдуцький I. П. Інвестування низьковуглецевої економіки: теорія, методологія, практика: монографія. Київ: Інформаційні системи, 2014. 373 с.

\footnotetext{
(C) Українська інженерно-педагогічна академія

(C) ГО «Школа адаптивного управління сочіально-педагогічними системами»

(C) Виговська В., Пищенко О.
} 
3. Галушкіна Т. П., Костецька К. О. «Зелена» економіка в секторальній моделі розвитку. Економічні інноващії. 2012. Вип. 48. С. 68-77.

4. Мельник Л. Г., Кубатко О. В. Ефективність використання природноресурсного потенціалу України та передумови формування «зеленої» економіки. Вісник соиіально-економічних досліджень. 2013. № 3. С. 169-174.

5. Потапенко В. Г. Стратегічні пріоритети безпечного розвитку України на засадах «зеленої економіки»: монографія. Київ: НІСД, 2012. 359 с.

6. Саблук П. Т. Інноваційна модель розвитку аграрного сектору економіки України та роль науки в ii становленні. Проблеми інноваційноінвестииійного розвитку. 2011. № 2. С. 200-208.

7. Ходаківська О. В. Екологізація аграрного виробництва: монографія. Київ: ННЦ ІАЕ, 2015. 350 с.

8. Ходаківська О. В. Екологізація аграрного виробництва: сучасні виклики та перспективи розвитку. Економіка АПК. 2015. № 5. С. 43-47.

\section{References}

1. Burkynskyi B. V., Halushkina T. P., and Reutov V. Ye. (2011), "Zelena" ekonomika kriz pryzmu transformatsiinykh zrushen v Ukraini ["Green" economy through the lens of transformational shifts in Ukraine]. Odesa: Feniks, 348 p. [Ukraine].

2. Haidutskyi I. P. (2014), Investuvannia nyzkovuhletsevoi ekonomiky: teoriia, metodolohiia, praktyka [Investment low-carbon economy: theory, methodology, practice]. Kyiv: Informatsiini systemy, 373 p. [Ukraine].

3. Halushkina T. P. and Kostetska K. O. (2012), "Zelena ekonomika v sektoralnii modeli rozvytku" ["Green economy in sectoral development model"], journal Ekonomichni innovatsii, [Economic innovation], vol. 48, pp. 68-77 [Ukraine].

4. Melnyk L. H. and Kubatko O. V. (2013), "Efektyvnist vykorystannia pryrodno-resursnoho potentsialu Ukrainy ta peredumovy formuvannia zelenoi» ekonomiky" ["The efficiency of natural-resource potential of Ukraine and the prerequisites for the formation of "green" economy"], journal Visnyk sotsialnoekonomichnykh doslidzhen [Bulletin of socio-economic research], vol. 3, pp.169-174 [Ukraine].

5. Potapenko V. H. (2012), Stratehichni priorytety bezpechnoho rozvytku Ukrainy na zasadakh zelenoi ekonomiky [Strategic priorities the safe development of Ukraine on the principles of green economy]. Kyiv: NISD, 359 p. [Ukraine].

6. Sabluk P. T. (2011), "Innovatsijna model' rozvytku ahrarnoho sektoru ekonomiky Ukrainy ta rol' nauky v ii stanovlenni" ["Innovative model of develop ment of the agrarian sector of Ukraine's economy and the role of science in its formation"], journal Problemy innovatsijno investytsijnoho rozvytku [Problems of innovation and investment development], vol. 2, pp. 200-208 [Ukraine].

\footnotetext{
(C) Українська інженерно-педагогічна академія

(C) ГО «Школа адаптивного управління сочіально-педагогічними системами»

(C) Виговська В., Пищенко О.
} 
7. Khodakivska O. V. (2015), Ekolohizatsiia ahrarnoho vyrobnytstva [Ecologization of agricultural production]. Kyiv: NNTs IAE, 350 p.[Ukraine].

8. Khodakivska O. V. (2015), "Ekolohizatsiia ahrarnoho vyrobnytstva: suchasni vyklyky ta perspektyvy rozvytku" ["Ecologization of agrarian production: modern challenges and perspectives of development"], journal Ekonomika APK [APK economy], vol. 5, pp. 43-47 [Ukraine].

ВЫГОВСКАЯ ВАЛЕНТИНА, доктор экономических наук, профессор,

Национальный университет «Черниговская политехника», г. Чернигов, Украина

ПИЩЕНКО АЛЕКСАНДР, кандидат экономических наук, Национальный университет «Черниговская политехника», г. Чернигов, Украина

\title{
НАПРАВЛЕНИЯ И ИНДИКАТОРЫ ИНСТИТУЦИОНАЛЬНОГО ОБЕСПЕЧЕНИЯ ЭКОЛОГО-ЭКОНОМИЧЕСКОЙ БЕЗОПАСНОСТИ АГРАРНОГО СЕКТОРА УКРАИНЫ
}

\begin{abstract}
Аннотация. Доказана актуальность исследования институционального обеспечения эколого-экономической безопасности аграрного сектора. Результаты проведенного анализа позволили констатировать, что в Украине на сегодняшний день не существует скоординированного механизма регулирования эколого-экономической безопасности аграрного сектора, органы регулирования действуют по централизованной модели, организационная структура и функциональная система не отвечает требованиям обеспечения эколого-экономической безопасности аграрного сектора. Обоснованы стратегические направления нейтрализации конфликтных ситуаций и гармонизации интересов субъектов обеспечения эколого-экономической безопасности аграрного сектора, которые предусматривают: изменение парадигмы развития аграрного сектора с технократической в экологически безопасную; формирование действенного механизма регулирования экологоэкономической безопасности аграрного сектора благодаря рациональному сочетанию рыночных и государственных рычагов воздействия, направленных на предсказания и предупреждения угроз; оптимизацию институционального обеспечения эколого-экономической безопасности аграрного сектора. Институционализация процесса обеспечения эколого-экономической безопасности включает в себя привлечение широкого круга участников вместе

(С) Українська інженерно-педагогічна академія

(C) ГО «Школа адаптивного управління соціально-педагогічними системами»

(C) Виговська В., Пищуенко О.
\end{abstract}


с их собственными целями и присущими им функциями. Функционирование аграрного сектора зависит от следующих характеристик хозяйственной динамики: материальные потребности, хозяйственные ориентиры и интересы, определенная под их влиянием мотивация к хозяйственной деятельности. Прежде всего, субъектами обеспечения эколого-экономической безопасности являются органы законодательной, исполнительной и судебной власти в пределах своих установленных законом полномочий.

Ключевые слова: аграрный сектор, эколого-экономическая безопасность, институциональный, обеспечение.

\author{
VYHOVSKA VALENTINA, \\ Doctor of Economics, Professor, \\ Professor of the National \\ University "Chernihiv \\ Polytechnic", \\ Ukraine
}

PISHCHENKO ALEXANDER, Candidate of Economic Sciences, National University "Chernihiv Polytechnic", Ukraine

\title{
DIRECTIONS AND INDICATORS OF INSTITUTIONAL SUPPORT OF ECOLOGICAL AND ECONOMIC SAFETY OF THE AGRICULTURAL SECTOR OF UKRAINE
}

\begin{abstract}
The relevance of the study of institutional support of ecological and economic security of the agricultural sector is proved. The results of the analysis revealed that in Ukraine today there is no coordinated mechanism for regulating the environmental and economic safety of the agricultural sector, regulators operate on a centralized model, organizational structure and functional system does not meet the requirements of environmental and economic safety of the agricultural sector. Strategic directions of neutralization of conflict situations and harmonization of interests of subjects of maintenance of ecological and economic safety of agrarian sector are substantiated, which provide: change of a paradigm of development of agrarian sector from technocratic to ecologically safe; formation of an effective mechanism for regulating the environmental and economic safety of the agricultural sector through a rational combination of market and state levers of influence aimed at anticipating and preventing threats; optimization of institutional support for environmental and economic security of the agricultural sector. Institutionalization of the process of ensuring environmental and economic security includes the

(C) Українська інженерно-педагогічна академія

(C) ГО «Школа адаптивного управління сочіально-педагогічними системами»

(C) Виговська В., Пищенко О.
\end{abstract}


involvement of a wide range of participants, along with their own goals and their inherent functions. The functioning of the agricultural sector depends on the following characteristics of economic dynamics: material needs, economic landmarks and interests, the motivation to economic activity determined under their influence. First of all, the subjects of environmental and economic security are the legislative, executive and judicial authorities within their statutory powers.

Key words: agricultural sector, ecological and economic security, institutional, provision. 